\title{
By Me Shall He Be Nursed! Queer Identity and Representation in The Mahabharata
}

\author{
Seema Sinha ${ }^{1} \&$ Kumar Sankar Bhattacharya ${ }^{2}$ \\ 1Ph. D from BITS Pilani, Pilani Campus, Rajasthan. Email: p2015101@pilani.bits-pilani.ac.in \\ ${ }^{2}$ Associate Professor in the Department of Humanities and Social Sciences, BITS Pilani, Pilani \\ Campus, Rajasthan. Email: kumar.bhattacharya@pilani.bits-pilani.ac.in
}

\begin{abstract}
The Mahabharata is a treasure-trove of the cultural memories of the Hindus. The grand Epic has entertained and edified our society through its numerous identity-relevant narratives since time immemorial. The longevity of The Mahabharata lies in its capacity to adapt, adopt and re-fashion the account, which grants endless opportunities of initiating open-ended debate. The grand Epic has shaped our values and shared a template by which a life guided by Dharma is to be lived. The dialogic text continues to contribute to the resolution of our emotional angst and existential dilemmas. Much ahead of its times, the Epic revels in the liminality that is apparent in the narratives of the gender-queer people who are an integral part of its culture-scape. This paper seeks to study two liminal figures in the Epic narrative - Shikhandi, the transgender Prince of Panchala, and Yuvanashwa, the pregnant King, who swayed between gendered identities and challenged the hegemonic heteronormative sexual framework, thereby opening avenues of conversation related to marginalization, resistance and empowerment. The paper also examines the queer cases of King Sudyumna and King Bhangashwan, who questioned the symbolic binaries of gender and delineated a horizon of possibilities. The aim here is to measure the resistance of the genderqueer against the prescriptive order of subjectivities and assess the impact and the outcome. Drawing from the deconstructivist and the queer theories, the study foregrounds the trauma and the resistance of the marginal. These narratives establish The Mahabharata as one of the earliest texts to have a meaningful discourse in the queer-space.
\end{abstract}

Keywords: Genderqueer, cultural memories, liminal, hegemonic, heteronormative, trauma, resistance

The Mahabharata is a treasure-trove of the cultural memories of the Hindus. The grand Epic has entertained and edified our society through its numerous identity-relevant narratives since time immemorial. The longevity of The Mahabharata lies in its capacity to adapt, adopt and re-fashion the account, which grants endless opportunities of initiating open-ended debate. The grand Epic 
has shaped our values and shared a template by which a life guided by Dharma is to be lived. The dialogic text continues to contribute to the resolution of our emotional angst and existential dilemmas. Much ahead of its times, the Epic revels in the liminality that is apparent in the narratives of the gender-queer people who are an integral part of its culture-scape. This paper seeks to study two liminal figures in the Epic narrative - Shikhandi, the trans-gender Prince of Panchala, and Yuvanashwa, the pregnant King, who swayed between gendered identities and challenged the hegemonic heteronormative sexual framework, thereby opening avenues of conversation related to marginalization, resistance and empowerment. The paper also examines the queer cases of King Sudyumna and King Bhangashwan, who questioned the symbolic binaries of gender and delineated a horizon of possibilities. The aim here is to measure the resistance of the genderqueer against the prescriptive order of subjectivities and assess the impact and the outcome. Drawing from the deconstructivist and the queer theories, the study foregrounds the trauma and the resistance of the marginal. These narratives establish The Mahabharata as one of the earliest texts to have a meaningful discourse in the queer-space.

While deliberating on the assessment of personalities that are in a state of flux and forever 'becoming', Browne and Nash (2016) posit that the Queer methodology draws on postmodernism and shares concerns with feminism, gay/lesbian activism and anti-racism (p.1). They observe that Queer theory negates the prescriptive order of subjectivities along the dominant binary and questions the privileging of heterosexual alliances as 'natural' (Queer Methods, p. 3). Andrea Custodi (2007) brings out the interesting dynamics that can result from the subversion of ostensibly stable categories ('Show you are a Man! p.211). She questions the biological essentialism of masculinity and femininity, and views them as symbolic positions. Though Brodbeck and Black (2007) acknowledge the liminality of the queer characters in the Epic, they assert that ultimately the dynamics are administered by the notions of masculinity (p.20). Judith Butler (1990) rightly points out that gender is culturally formed, yet the heteronormative society targets those who are nonconforming as to gender performance (p.137).

That this mindset has a hoary history is evident in the fascinating account of Shikhandi, the trans-gender prince of Panchal, whose birth was a major embarrassment - nay, a crisis, for the parents. Assigned male at birth, Shikhandi lived a life of trauma and guilt for no fault of his, to the extent that he contemplated suicide when his parents fixed his marriage with the princess of Dasharna. The marriage was solemnized but not consummated, and the distraught bride called out the hoax:

हिरण्यवर्मणः कन्या ज्ञात्वा तां तु शिखण्डिनीम्।

धात्रीणां च सखीनां च त्रीडमाना न्यवेदयत् ||९४॥

कन्यां पश्चालराजस्य सुतां तां वै शिखण्डिनीम् ||२४|| The Mahabharata BORI5:190 
When the father of the bride, the King of Dasharna, came to know of the developments, he declared war. Drupada, the father of Shikhandi, was given the option of proving the 'manhood' of his 'son', a recurring theme in the Epic. When asked by Drupada as to why the birth was misreported, his queen (Shikhandi's hapless mother) shared that she was terrified of being proclaimed barren if she did not give birth to a son. Barrenness was of multiple types, and a woman who had only daughters, was 'Kak-vandhya' (almost barren). And if she had a trans-gender progeny, she was doomed, hence the misreported news of the birth of a son by Drupada's wife, the mother of Shikhandi. The Epic states:

अपुत्रया मया राजन्सपत्नीनां भयादिदम्|

कन्या शिखण्डिनी जाता पुरुषो वै निवेदितः ||र|| The Mahabharata BORI5:192

No one thought of the trauma this will inflict on Shikhandi, the trans-gender progeny, who had to prove that he was a male. Witnessing the parents in this pathetic condition, and unable to change his gender to the desired one, Shikhandi contemplated suicide:

ततः सा चिन्तयामास मत्कृते दु:खितावुभौ ।

इमाविति ततश्चक्रे मतिं प्राणविनाशने \|१८ $\|$ The Mahabharata BORI 5:190

Shikhandi's departure to the forest to commit suicide is reported with great sensitivity in the Epic. As luck would have it, or as Lord Shiva's bounty would have it, Shikhandi's destiny was about to change. In a dramatic twist of fate, he met a demi-god in the forest - a Yaksha called Sthunakarna', who was moved by the trans-gender's plight, and promised to grant him male attributes for a short while. The Yaksha would, for that time-period, become a woman and wait for his manhood to be returned:

धनेश्वरस्यानुचरो वरदोऽस्मि नृपात्मजे |

अदेयमपि दास्यामि ब्रूहि यत्ते विवक्षितम् ||२५| The Mahabharata BORI3.191

स्त्रीलिड़ं: धारयिष्यामि त्वदीयं पार्थिवात्मजे |

The Mahabharata BORI3.192

The happy prince assured a quick return of the gift of masculinity after the purpose was served, that is, after his marriage was consummated, and the danger of war was averted:

प्रतिदास्यामि भगवँल्लिड़ं. पुनरिदं तव |

किश्चित्कालान्तरं स्त्रीत्वं धारयस्व निशाचर || | The Mahabharata BORI3.193

The task accomplished, Shikhandi went back to communicate to his father Drupada that he had finally attained masculinity. This news was quickly relayed to the King of Dasharna, the father of the bride. The sceptic father-in-law would not take the son-in-law for his word, so he 
dispatched many women, well-versed in the ways of the world, to verify the claim. To his surprise and great happiness, the ladies reported that Shikhandi indeed was a male:

ततः स राजा द्रुपदस्य श्रुत्वा; विमर्शयुक्तो युवतीर्वरिष्ठाः |

सम्प्रेषयामास सुचारुरूपाः; शिखण्डिनं स्त्री पुमान्वेति वेत्तुम् ||२५

ताः प्रेषितास्तत्त्वभावं विदित्वा; प्रीत्या राजे तच्छशंसुर्हि सर्वम्।

शिखण्डिनं पुरुषं कौरवेन्द्र; दशार्णराजाय महानुभावम् ॥२६॥

The Mahabharata BORI 5:193: 25, 26

The transaction was supposed to be temporary, but the crisis was resolved by a parallel narrative. The Epic reports that Sthunakarna, the well-meaning Yaksha, could not take back his manhood, because he was cursed by his master Kubera to forever remain a woman. This gave Shikhandi a chance to become a male on a more permanent basis. The stage was now set for Shikhandi, the male, to avenge an insult that was part of the transcendental memories of his previous birth as a woman. For Shikhandi was Amba in his past life - Amba, the princess of Kashi, who was abducted and spurned by Bhishma, and swore revenge on the patriarch. Amba died before she could fulfil her wish, but the memories of the previous birth remained, and the revenge was served cold. Shiva, the 'great God'(Mahadeva), understood the pain of the marginal, and promised Amba:

छन्द्यमाना वरेणाथ सा वव्रे मत्पराजयम् |वधिष्यसीति तां देवः प्रत्युवाच मनस्विनीम् ||C

The Mahabharata BORI5:187

[ 'The words I have uttered cannot be false. O blessed lady, true they will be. Thou shalt slay Bhishma, and even obtain manhood.' (The Mahabharata, translated by K. M. Ganguli, Book 5: Udyoga Parva: Uluka Dutagamana Parva: Section CXC)]

Amba, a woman, could subvert hypermasculinity by being re-born as Shikhandi, the transgender, making it a common front against the oppressor. According to Butler (1988), since gender was a parody, a choice, or a role, or rather a construction, drag suggested a conflict between sex and performance (Bodies That Matter, p.21). David Halperin defined Queer identity as a positionality, as Queer was forever at odds with the normative, the regular and the hegemonic. Halperin found 'Queer' delineating an 'identity minus an essence', a positionality against the normative, thereby demarcating a horizon of possibility (p.62). This positionality is apparent in the second queer narrative that we take up for our study - that of Yuvanashwa, the Pregnant King, who gave birth to a son. Since Lord Indra, another male, took the responsibility of nursing the infant, the new-born was named 'Mandhata' (By me shall he be nursed!).

मामयं धास्यतीत्येवं परिभाष्टः स वज्रिणा |

मान्धातेति च नामास्य चक्रुः सेन्द्रा दिवौकसः ||२८\| The Mahabharata BORI 3:126 
Story goes that Yuvanashwa, the King of Vallabhi, had a wife who was barren and could not conceive. A yajna was performed, and a pot of holy water consecrated and kept aside for her to partake, so that she could become fertile again. But in a startling development, Yuvanashwa, who had gone out hunting, came back and accidently drank the holy water meant for his wife:

शुष्ककणठः पिपासार्तः पाणीयार्थी भृशं नृपः | तं प्रविश्याश्रमं श्रान्तः पाणीयं सोऽभ्ययाचत ॥१२॥

The Mahabharata BORI3:126

The mantras were powerful, and in due course of time the King became pregnant and gave birth to a son, who was nursed by Lord Indra for want of a mother. This unique phenomenon of one-male giving birth and another male nursing the infant is a fascinating case of gender-bending. If Shikhandi was a distraught prince in the first narrative, both Yuvanashwa, the ruler of Vallabhi, and Lord Indra, the King of gods, were unapologetic about their queerness in the second narrative, and were power figures in their own right. The changing dynamics are manifest in the glowing terms in which the birth of the son to the trans-couple is proclaimed:

ततो वर्षशते पूर्णे तस्य राज्ञो महात्मनः | वामं पार्श्वं विनिर्भिद्य सुतः सूर्य इवापरः ||२५|

The Mahabharata BORI3:126

The progeny christened Mandhata was born after splitting the left thigh of the father. Mandhata went on to become a Chakravartin King, and his queer lineage was respected by all. The introspection and the doubts that King Yuvanashwa may have had were resolved, giving us a glimpse of the changing dynamics, which had started accommodating the queer.

Yuvanashwa and Indra were not the only trans-couple who lived happily ever after. There was also the gender-bending account of the god Budha and Queen Ilaa, who swung between gendered identities (The Mahabharata, Adi Parva: Sambhava Parva: Section LXXV). It so happened that King Sudyumna wandered into the enchanted forest graced by God Shiva and Devi Parvati, and was turned into a woman for the offence. He begged for mercy, and Shiva being 'Ashutosh', the God who is easily pleased, altered the punishment. The new decree said that King Sudyumna would alternate between genders - he would be a man for one half of the month, and a woman for the other half. While a woman, King Sudyumna would be called Ilaa, the wife of planet Budha. While a man he would be called 'Il', the cherished mate of Budha. This swinging between genders is in sync with what Biddy Martin (1994) observes in Sexualities without Genders and other Queer Utopias. While discussing the contradiction set up between the traditional perception of gender as a stable core and postmodern conceptions of identity as the effect of discursive practice, Martin asserts that they need to be displaced and not decided in one direction or the other (p.118).

A discussion on queer sexuality would not be complete without the story of King Bhangashwan, who was cursed by Lord Indra into becoming a female. (Ganguli, Book 13: Anusasana Parva: Anusasanika Parva: Section XII). Eventually, Indra was placated, and he offered 
to return King Bhangashwan his masculinity, but the King who had appreciated femininity and motherhood declined to become a man again (ibid). By refusing masculinity and embracing femininity, King Bhangashwan proved that gender was not cast in stone. Foucault (1978) says that there is no single site of great Refusal, because there is always a plurality of resistances (The History of Sexuality, pp.95-6). The degree may vary, but the will to resist is obvious, as we see in the narratives of princess Amba who was reborn as prince Shikhandi, Yuvanashwa, the pregnant King, Sudyumna who swung between gender-identities, Bhangashwan, who refused to revert back to manhood, and several others whose stories have gone partially documented or not documented at all. Judith Halberstam (1994) observes that if gender is a fiction that we all read in different manner, then it is also possible to rewrite the same. She questions the transsexual models that assign gender deviance only to transsexual bodies and gender normativity to all other bodies, as also the heteronormative models that see transsexuality as gender deviance and homosexuality as a pathological perversion (F2M: The Making of Female Masculinity, pp.153-4). Jana Sawicki (1988) points out that bodies are produced, comprehended, and utilized in the context of the relationships of power (pp.186-190). Foucault (1978) asserts that amongst the plurality of resistances, some are probable, some improbable, some spontaneous, some savage, while others that are quick to compromise, or even sacrificial (The History of Sexuality, p. 96). He regrets that the system of distinction, opposition and exclusion has defined our perception of sexuality (The Subject and Power, pp. 780-781). Calvin Thomas (2017), in his work titled No Kingdom of the Queer, notes that Queerness can never define an identity - it can only ever disturb one (p. 3).

The fallacy of an unchanging gender core is discursively upheld across world literature, yet in the stories taken up for our study we observe that there are narratives of resistance documented in the margins and the interstices of the texts, introducing spaces of conversation pertaining to queer sexuality, narratives of oppression and resistance. That makes The Mahabharata one of the earliest texts to have discourse in the queer space. Whether it is to criticise, to condemn, to shun, or to laud - the queer was given a place in the narrative. Of course, not everyone had the courage to acknowledge their queer sensitivities, or the agency to overcome the denouncement. We have innumerable examples of contempt expressed towards the third gender in The Mahabharata. Yet the fact that Shikhandi, Yuvanashwa, Sudyumna or Bhangashwan and others gender-fluid characters could emerge as power-figures and role-models, speaks volumes in terms of queer-resistance and representation, the pinnacle of which was the worship of Shiva as 'Ardha-Narishwara', and Vishnu as 'Mohini'.

Our study leads us to believe that questioning essentialism by encouraging the multiplicity of sexualities had an extended history in India. The gender-queer characters that populated the Epic had to swing between identities, justify their existence, and even take re-birth to resolve the existential angst and the memories of trauma. Yet, slowly, but surely, they proved that bodies can be gender-strange, and should be accepted as that. "The underground language of people, who 
7 By Me Shall He Be Nursed! Queer Identity and Representation in The Mahabharata

have no power to define and determine themselves in the world, develops its own density and precision. It enables them to sniff the wind, sense the atmosphere and defend themselves in a hostile terrain," says Sheila Rowbotham. The trans-gender people were born in negation - they were neither man nor woman - so they could not speak in the language of either gender. Still, as we have seen in the examples studied in this paper, an effort was made to register the trauma faced by the genderqueer, and to recognize their attempt at subversion. This paper celebrates the narratives of resistance put up by the gendered marginal in a hegemonic, heterosexual, and hierarchical world.

\section{References}

Brodbeck, S. and Brian B. (2007). Gender and Narrative in the Mahabharata. Routledge Publishers.

Browne, K. and Catherine J. N. (2016). Queer Methods and Methodologies: Intersecting Queer Theories and Social Science Research. Routledge Publishers.

Butler, J. (1988). "Performative Acts and Gender Constitution: An Essay in Phenomenology and Feminist Theory." Theatre Journal, vol. 40, no. 4, 1988, pp. 519-531. JSTOR, www.jstor.org/stable/3207893. Accessed 11 1. 2020.

https://monoskop.org/images/d/df/Butler_Judith_Bodies_That_Matter_On_the_Discursive_Limits_of_Se x_1993.pdf

Foucault, M. (1978). The History of Sexuality -Volume 1: An Introduction. Pantheon Books.

Halberstam, J. (1994). "F2M: The Making of Female Masculinity," The Lesbian Postmodern. Laura Doan, ed. New York: Columbia University Press, 1994, pp. 210-28.

Halperin, D. (1995). Saint Foucault: Towards a Gay Hagiography. Oxford University Press.

Martin, B. (1994). Sexualities without Genders and Other Queer Utopias. Diacritics, 24(2/3),

Rowbotham, S. (2015). https://www.perlego.com/book/730864/womans-consciousness-mans-worldpdf104-121. doi:10.2307/465167

Sawicki, J. (1988). "Identity politics and sexual freedom: Foucault and feminism". In Feminism and Foucault: Reflections on Resistance, edited by I. Diamond and L. Quinby, Northeastern University Press, 1988, pp.177-192.

Thomas, C. (2017). No Kingdom of the Queer

https://www.academia.edu/34296976/No_Kingdom_of_the_Queer_in_Derrida_and_Queer_Theory_edited_b y_Christian_Hite_Punctum_2017

Vyasa, Krishna-Dwaipayana. The Mahabharata. Sanskrit Documents.18 Volumes. Bhandarkar Oriental Research Institute (BORI), Sanskrit Documents, 23.4.1998

(updated 2013) <http://sanskritdocuments.org/mirrors/mahabharata/mahabharata-bori.html> 
---. The Mahabharata. Translated by Kisari Mohan Ganguli. 1883-96.

http://www.sacredtexts.com/hin/maha/index.htm

Dr. Seema Sinha has done her Ph. D from BITS Pilani, Pilani Campus, Rajasthan. She is an M. Phil in History from Jawaharlal Nehru University, New Delhi and a UGC Fellow. Her Doctoral research centers on the Indian mythic characters who exist in liminality and on the threshold of condemnation/celebration.

Dr. Kumar Sankar Bhattacharya is an Associate Professor in the Department of Humanities and Social Sciences, BITS Pilani, Pilani Campus, Rajasthan. An alumnus of Drew University, Madison, NJ, USA, Dr. Bhattacharya has worked extensively on Postcolonial Theory, Trans-national and Global Literature. 